Check for updates

Cite this: RSC Adv., 2017, 7, 30640

\title{
Hydroquinone derivatives from the marine-derived fungus Gliomastix sp. $\dagger$
}

\author{
Mohamed S. Elnaggar, ${ }^{\text {ab }}$ Weaam Ebrahim, ${ }^{\text {ac }}$ Attila Mándi, ${ }^{d}$ Tibor Kurtán, ${ }^{d}$ \\ Werner E. G. Müller, (iD ${ }^{e}$ Rainer Kalscheuer, ${ }^{a}$ Abdelnasser Singab, ${ }^{b}$ Wenhan Lin, (D) \\ Zhen Liu (D) ${ }^{* a}$ and Peter Proksch*a
}

Eight new hydroquinone derivatives, gliomastins A-D (1-4), 9-O-methylgliomastin C (5), acremonin A 1-O$\beta$-D-glucopyranoside (6), gliomastin E 1-O- $\beta$-D-glucopyranoside (7), and 6'-O-acetyl-isohomoarbutin (8), together with seven known analogues were isolated from the marine-derived fungus Gliomastix sp. Their structures were elucidated by extensive spectroscopic analysis including 1D and 2D NMR measurements aided by DFT NMR calculations as well as MS data. TDDFT-ECD and OR calculations were performed to determine the absolute configurations of 1 and the aglycones of 6 and 7. Compound 1 features a novel skeleton, biogenetically derived from a Diels-Alder reaction between derivatives of 11 and 13 . Compound 2 represents a rare sulfur-containing alkaloid derived from the known hydroquinone 13. Compounds 1, 10 and 12 showed strong cytotoxicity against the L5178Y mouse lymphoma cell line with $I_{50}$ values of $1.8,1.0$ and $1.1 \mu \mathrm{M}$, respectively. Compound 3 exhibited moderate antitubercular activity against Mycobacterium tuberculosis with a MIC value of $12.5 \mu \mathrm{M}$.

Received 2nd May 2017

Accepted 3rd June 2017

DOI: $10.1039 / \mathrm{c} 7 \mathrm{ra04941b}$

rsc.li/rsc-advances acetylcholinesterase inhibitory activity. ${ }^{6}$ Hydroanthraquinones and anthraquinone dimers, which were isolated from the soft coral-derived fungus Alternaria sp., showed cytotoxicity against PC-3 and HCT-116 tumor cell lines. ${ }^{7}$ In addition, the structurally unique 14-membered resorcylic acid lactones cochliomycins AC, which exhibit antifouling activity, were isolated from the gorgonian-derived fungus Cochliobolus lunatus. ${ }^{8}$

As a part of our ongoing exploration of bioactive metabolites from fungi, ${ }^{9-12}$ examination of the Red Sea derived hard coral Stylophora sp. collected in Egypt, afforded different fungal strains from the coral tissues, ${ }^{9}$ one of which was identified as Gliomastix sp. So far only few secondary metabolites have been reported from the genus Gliomastix, including the macrolides gliomasolide A-E, ${ }^{13}$ the dihydroxanthenones muroxanthenone $\mathrm{A}-\mathrm{E},{ }^{\mathbf{1 4}, \mathbf{1 5}}$ as well as quinone/hydroquinone meroterpenoids. ${ }^{\mathbf{1 6}}$ The crude extract of the solid rice culture of Gliomastix sp. in this study showed cytotoxic activity against the L5178Y mouse lymphoma cell line with inhibition rate of $69.1 \%$ at a dose of 10 $\mu \mathrm{g} \mathrm{mL}{ }^{-1}$. Chromatographic workup of the fungal extract afforded fifteen hydroquinone derivatives including eight new natural products (1-8). Herein, we report the isolation, structure elucidation as well as cytotoxic and antimicrobial activity of the isolated compounds.

\section{Results and discussion}

Compound 1 was isolated as a yellow amorphous powder. Its molecular formula was determined to be $\mathrm{C}_{22} \mathrm{H}_{22} \mathrm{O}_{4}$ by HRESIMS, indicating twelve degrees of unsaturation. The ${ }^{13} \mathrm{C}$ NMR 


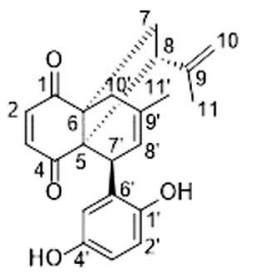

1<smiles>O=C(O)C1C(=O)c2c(O)ccc(OC3O[C@H](CO)[C@@H](O)[C@H](O)[C@H]3O)c21</smiles><smiles>CC(C)=CCc1cc(O)ccc1O</smiles>

12

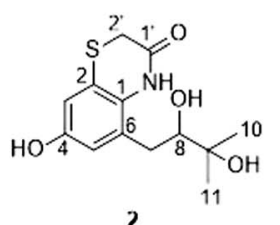

2<smiles>[R]C([2H])([2H])C([2H])c1cc2cc(O)ccc2o1</smiles>

$5 \mathrm{R}=\mathrm{Me}$<smiles>[3H]C1Oc2ccc(O)cc2C=C1O</smiles>

4<smiles>Cc1cc(O)ccc1O</smiles>

10

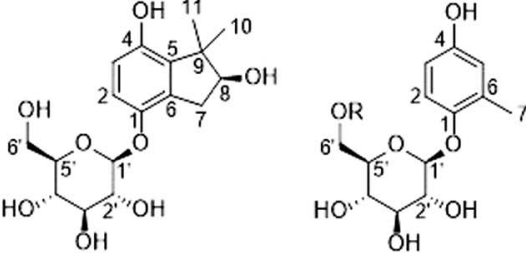

$8 \mathrm{R}=\mathrm{Ac}$ $9 \mathrm{R}=\mathrm{H}$<smiles>C=C(C)[C@H]1Cc2c(O)ccc(O)c21</smiles>

11<smiles>CC(C)(O)C(O)Cc1cc(Cl)ccc1O</smiles>

13<smiles>CC(C)(O)C1Cc2cc(O)ccc2O1</smiles>

14<smiles>CC1(C)Oc2ccc(O)cc2C[C@H]1O</smiles>

15 data of 1 (Table 1) together with HSQC and HMBC spectra revealed the presence of 22 carbons, including two carbonyl groups $\left(\delta_{\mathrm{C}} 202.3\right.$ and 200.5), twelve olefinic or aromatic carbons $\left(\delta_{\mathrm{C}} 110-151\right)$ and eight aliphatic carbons (two quaternary carbons at $\delta_{\mathrm{C}} 59.8$ and 47.6, two methines at $\delta_{\mathrm{C}} 48.0$ and 46.8 , two methylenes at $\delta_{\mathrm{C}} 36.9$ and 36.5, and two methyls at $\delta_{\mathrm{C}} 24.5$ and 23.5). The ${ }^{1} \mathrm{H}$ NMR spectrum of 1 (Table 1) displayed five olefinic protons at $6.73(\mathrm{~d}, \mathrm{H}-2), 6.50(\mathrm{~d}, \mathrm{H}-3), 5.68$ (br s, H-8'),

Table 1 NMR data for compounds 1 and 2

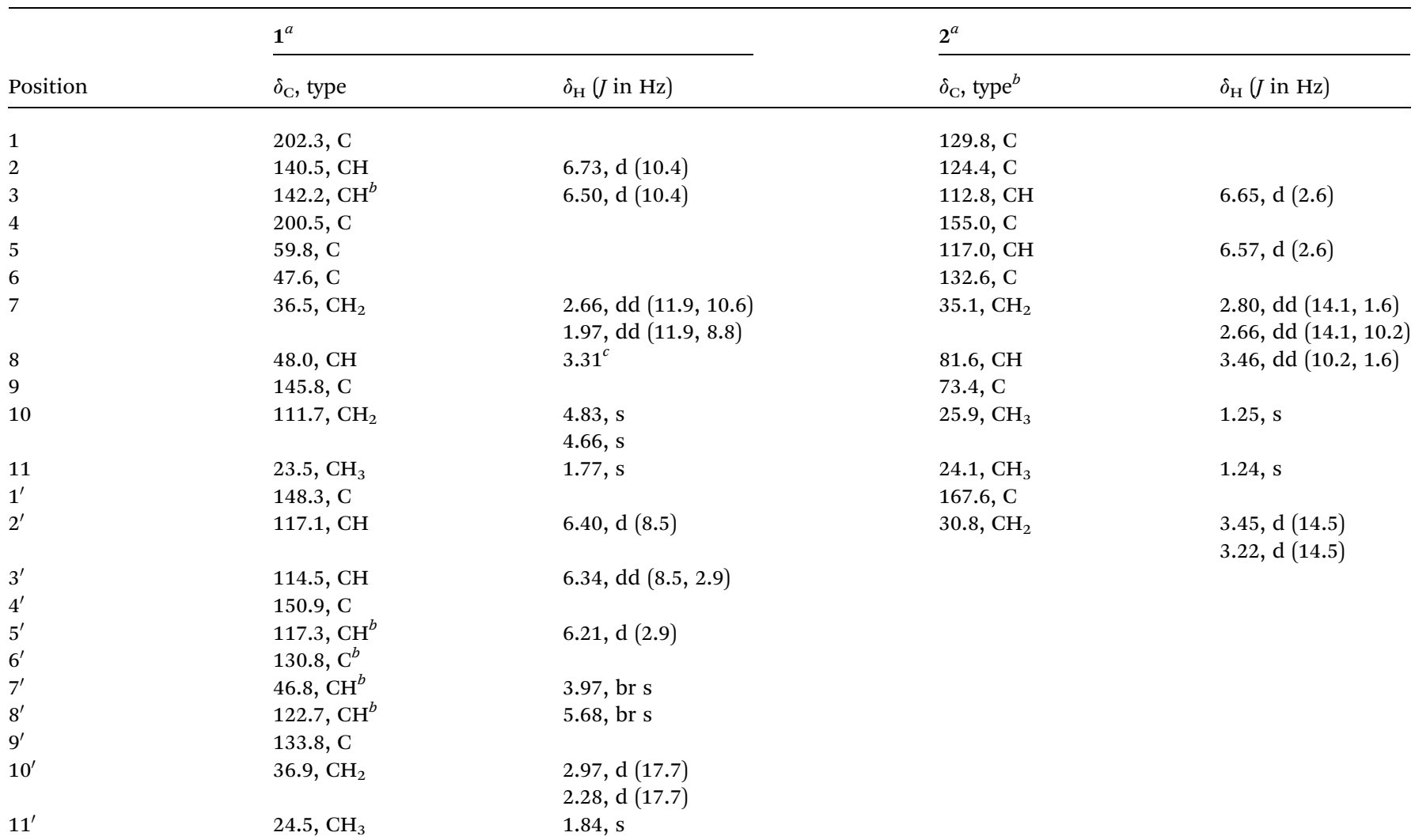

${ }^{a}$ Recorded at $600 \mathrm{MHz}$ for ${ }^{1} \mathrm{H}$ and $150 \mathrm{MHz}$ for ${ }^{13} \mathrm{C}$ in $\mathrm{CD}_{3} \mathrm{OD} .{ }^{b}$ Data extracted from HSQC and HMBC spectra. ${ }^{c}$ Overlapped with water peak. 
4.83 (br s, H-10a) and 4.66 (br s, H-10b), representing a disubstituted double bond, a trisubstituted double bond and a terminal double bond, respectively. In addition, three aromatic protons of an ABX ring system at $\delta_{\mathrm{H}} 6.40\left(\mathrm{~d}, \mathrm{H}-2^{\prime}\right), 6.34$ (dd, H-3') and 6.21 (d, H-5') as well as two methyls at 1.84 (s, Me$11^{\prime}$ ) and 1.77 (d, Me-11) were observed. These data accounted for nine degrees of unsaturation. Thus, compound 1 must possess a tricyclic skeleton in addition to an aromatic ring. The presence of a cyclohexenedione ring in 1 was established by the COSY correlation between $\mathrm{H}-2$ and $\mathrm{H}-3$ along with the HMBC correlations from $\mathrm{H}-2$ to $\mathrm{C}-4\left(\delta_{\mathrm{C}} 200.5\right)$ and C-6 $\left(\delta_{\mathrm{C}} 47.6\right)$ and from $\mathrm{H}-3$ to $\mathrm{C}-1\left(\delta_{\mathrm{C}} 202.3\right)$ and $\mathrm{C}-5\left(\delta_{\mathrm{C}} 59.8\right)$ (Fig. 1). The COSY correlations between $\mathrm{H}-7 \mathrm{a}\left(\delta_{\mathrm{H}} 2.66\right.$, dd $) / \mathrm{H}-8\left(\delta_{\mathrm{H}} 3.31\right)$ and $\mathrm{H}-7 \mathrm{~b}$ $\left(\delta_{\mathrm{H}} 1.97, \mathrm{dd}\right) / \mathrm{H}-8$ together with the HMBC correlations from $\mathrm{H}-$ $7 \mathrm{a}$ to $\mathrm{C}-1$, from $\mathrm{H}-7 \mathrm{~b}$ to $\mathrm{C}-5$, from $\mathrm{H}-8$ to $\mathrm{C}-4$ and $\mathrm{C}-5$, and from Me-11 to C-8 $\left(\delta_{\mathrm{C}} 48.0\right), \mathrm{C}-9\left(\delta_{\mathrm{C}} 145.8\right)$ and C-10 $\left(\delta_{\mathrm{C}} 111.7\right)$ revealed that the cyclohexenedione ring was fused with a cyclobutane ring at the C-5 and C-6 positions and a isopropenyl group was attached at the $\mathrm{C}-8$ position. In addition, the COSY correlation between $\mathrm{H}^{-} 7^{\prime}\left(\delta_{\mathrm{H}} 3.97\right) / \mathrm{H}-8^{\prime}$ and the $\mathrm{HMBC}$ correlations from $\mathrm{H}$ $8^{\prime}$ to $\mathrm{C}-5$, from Me- $11^{\prime}$ to $\mathrm{C}-8^{\prime}\left(\delta_{\mathrm{C}} 122.7\right), \mathrm{C}-9^{\prime}\left(\delta_{\mathrm{C}} 133.8\right)$ and $\mathrm{C}-10^{\prime}$ $\left(\delta_{\mathrm{C}} 36.9\right)$, from $\mathrm{H}-10^{\prime} \mathrm{a}\left(\delta_{\mathrm{H}} 2.97, \mathrm{~d}\right)$ to $\mathrm{C}-1$, and from $\mathrm{H}-10^{\prime} \mathrm{b}\left(\delta_{\mathrm{H}}\right.$ $2.28, \mathrm{~d})$ to $\mathrm{C}-5$ and $\mathrm{C}-7\left(\delta_{\mathrm{C}} 36.5\right)$ indicated a cyclohexene ring with a methyl substituent at the $\mathrm{C}-9^{\prime}$ position, which was fused with the cyclohexenedione ring through the C-5/C-6 bridge. Moreover, the presence of a benzene ring substituted at the C-7' position was confirmed by the previous observation of an $\mathrm{ABX}$ aromatic spin system $\left(\mathrm{H}-2^{\prime}, 3^{\prime}\right.$ and $\left.5^{\prime}\right)$ and the HMBC correlations from $\mathrm{H}-2^{\prime}$ to $\mathrm{C}-4^{\prime}\left(\delta_{\mathrm{C}} 150.9\right)$ and $\mathrm{C}-6^{\prime}\left(\delta_{\mathrm{C}} 130.8\right)$, from $\mathrm{H}-3^{\prime}$ to $\mathrm{C}-1^{\prime}\left(\delta_{\mathrm{C}} 148.3\right)$ and $\mathrm{C}-5^{\prime}\left(\delta_{\mathrm{C}} 117.3\right)$, from $\mathrm{H}-5^{\prime}$ to $\mathrm{C}-3^{\prime}\left(\delta_{\mathrm{C}} 114.5\right)$, and from $\mathrm{H}-7^{\prime}$ to $\mathrm{C}-5^{\prime}$. Two hydroxy groups were suggested to be located at $\mathrm{C}-1^{\prime}$ and $\mathrm{C}-4^{\prime}$ as indicated by the chemical shifts of C$1^{\prime}$ and $\mathrm{C}-4^{\prime}$. Thus, the planar structure of 1 was elucidated as shown, for which the trivial name gliomastin A is proposed.

The relative configuration of $\mathbf{1}$ was determined by ROESY data (Fig. 1). The NOE correlations from $\mathrm{H}-7^{\prime}$ to $\mathrm{H}-8$ and $\mathrm{Me}-11$ suggested $\mathrm{H}-\mathrm{7}^{\prime}$ and the cyclobutane ring to be on the same face of the cyclohexene ring while the NOE relationships between $\mathrm{H}$ $8 / \mathrm{H}-7 \mathrm{~b}$ and $\mathrm{H}-7 \mathrm{~b} / \mathrm{H}-10^{\prime} \mathrm{b}$ indicated these protons to be orientated on the same side of the cyclobutane ring. In addition, DFT NMR calculations were performed on the arbitrarily chosen $\left(5 S, 6 R, 8 R, 7^{\prime} R\right)-\mathbf{1}$ and $\left(5 S, 6 R, 8 S, 7^{\prime} R\right)-\mathbf{1}$ epimers to decide between the $\left(5 S^{*}, 6 R^{*}, 8 R^{*}, 7^{\prime} R^{*}\right)$ and $\left(5 S^{*}, 6 R^{*}, 8 S^{*}, 7^{\prime} R^{*}\right)$ relative configuration of 1. Merck Molecular Force Field (MMFF) conformational searches of the two epimers resulted in 14 and 14 lowenergy conformers in a $21 \mathrm{~kJ} \mathrm{~mol}^{-1}$ energy window,
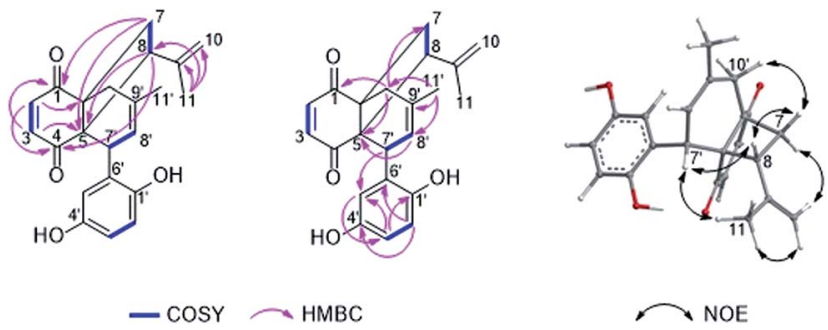

$-\mathrm{COSY} \sim \mathrm{HMBC}$

Fig. 1 Key COSY, HMBC and ROESY correlations of compound 1. respectively. These conformers were reoptimized at the B3LYP/ 6-31+G(d,p) level and NMR shift values were computed for conformers over 1\% Boltzmann population at the mPW1PW91/ $6-311+\mathrm{G}(\mathrm{d}, \mathrm{p})$ level. ${ }^{17}$ In accordance with the experimental NOE data, computed ${ }^{13} \mathrm{C}-\mathrm{NMR}$ chemical shifts of most carbons suggest $8 S^{*}$ relative configuration, while good agreement between experimental and computed ${ }^{1} \mathrm{H}$-NMR chemical shifts of the $8 S^{*}$ epimer compared to that of the $8 R^{*}$ epimer allowed unambiguous assignment of the relative configuration of $\mathbf{1}$ as $\left(5 S^{*}, 6 R^{*}, 8 S^{*}, 7^{\prime} R^{*}\right)$.

To determine the absolute configuration of $\mathbf{1}$, the solution TDDFT-ECD method was applied on the arbitrarily chosen $\left(5 S, 6 R, 8 S, 7^{\prime} R\right)$-1 enantiomer. ${ }^{\mathbf{1 8}, 19}$ The 14 MMFF conformers obtained in the conformational search of the NMR calculations were reoptimized at the B3LYP/6-31G(d), B97D/TZVP ${ }^{20,21}$ PCM/ MeCN and CAM-B3LYP/TZVP ${ }^{22,23}$ PCM/MeCN levels and ECD computations were performed for the low-energy conformers with various functionals (B3LYP, BH\&HLYP, CAM-B3LYP, PBE0) combined with the TZVP basis set. Computed ECD spectra obtained at all of the applied combination of levels gave moderate to good mirror-image agreement with the experimental spectrum, allowing determination of the absolute configuration of $\mathbf{1}$ as $\left(5 R, 6 S, 8 R, 7^{\prime} S\right)$ (Fig. 2).

Gliomastin A (1) features a new carbon skeleton, which could be derived from two co-isolated known hydroquinone derivatives acremonin A (11) ${ }^{24}$ and $\mathrm{F}-11334 \mathrm{~A}_{1}(\mathbf{1 3}) \cdot{ }^{25,26} \mathrm{~A}$ biosynthetic pathway from the latter two compounds to 1 via Diels-Alder reaction is proposed (Fig. 3).

The molecular formula of compound 2 was established as $\mathrm{C}_{13} \mathrm{H}_{17} \mathrm{NO}_{4} \mathrm{~S}$ by HRESIMS, requiring six degrees of unsaturation. In the ${ }^{1} \mathrm{H}$ NMR spectrum of 2 (Table 1), two meta-coupled aromatic protons at $\delta_{\mathrm{H}} 6.65(\mathrm{~d}, J=2.6 \mathrm{~Hz}, \mathrm{H}-3)$ and $6.57(\mathrm{~d}, J=$ $2.6 \mathrm{~Hz}, \mathrm{H}-5)$, one oxygenated methine at $\delta_{\mathrm{H}} 3.46(\mathrm{dd}, J=10.2$, $1.6 \mathrm{~Hz}, \mathrm{H}-8)$, one isolated methylene at $\delta_{\mathrm{H}} 3.45(\mathrm{~d}, J=14.5 \mathrm{~Hz}$,

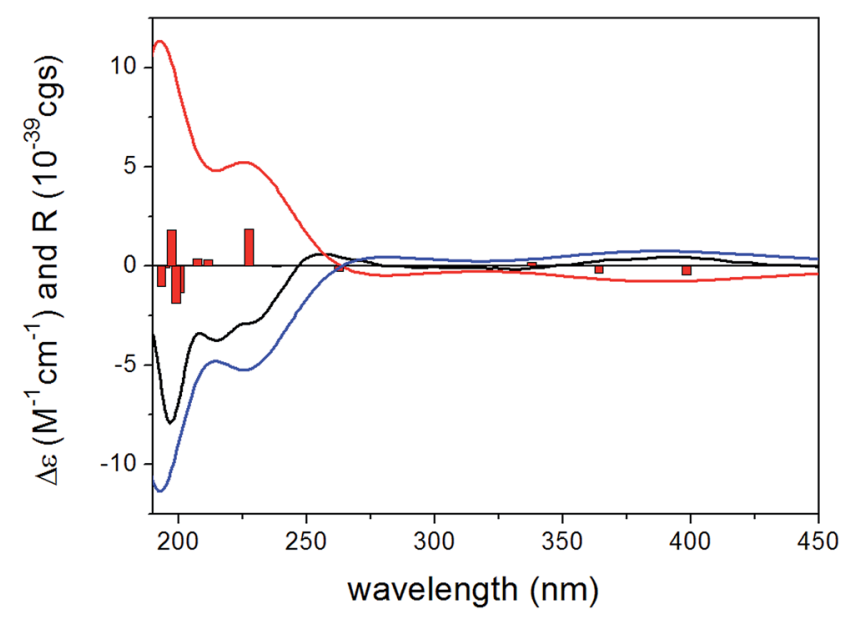

Fig. 2 Experimental ECD spectrum of 1 in $M e C N$ (black line) compared with the B3LYP/TZVP ECD spectra computed for the $\mathrm{B} 3 \mathrm{LYP} / 6-31 \mathrm{G}(\mathrm{d})$ in vacuo optimized low-energy conformers of $\left(5 S, 6 R, 8 S, 7^{\prime} R\right)-1$ (average of 4 conformers, red line) and $\left(5 R, 6 S, 8 R, 7^{\prime} S\right)$ 1 (average of 4 conformers, blue line). Bars represent computed rotational strength values of the lowest-energy conformer of $\left(5 S, 6 R, 8 S, 7^{\prime} R\right)-1$. 


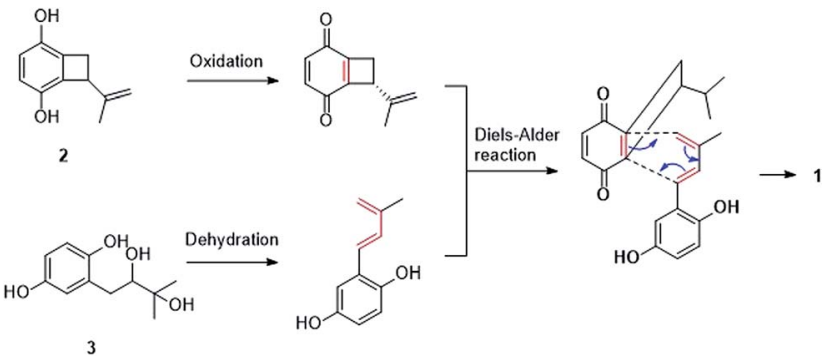

Fig. 3 A plausible biosynthetic pathway for compound 1.

$\left.\mathrm{H}-2^{\prime} \mathrm{a}\right)$ and $3.22\left(\mathrm{~d}, J=14.5 \mathrm{~Hz}, \mathrm{H}-2^{\prime} \mathrm{b}\right)$, one methylene at $\delta_{\mathrm{H}} 2.80$ (dd, $J=14.1,1.6 \mathrm{~Hz}, \mathrm{H}-7 \mathrm{a}$ ) and 2.66 (dd, $J=14.1,10.2 \mathrm{~Hz}, \mathrm{H}-7 \mathrm{~b})$, and two methyl groups at $\delta_{\mathrm{H}} 1.25$ (s, Me-10) and 1.24 (s, Me-11) were observed. The COSY correlations between $\mathrm{H}-7 \mathrm{a} / \mathrm{H}-8$ and $\mathrm{H}-$ $7 \mathrm{~b} / \mathrm{H}-8$ as well as the HMBC correlations from Me-10 and Me-11 to $\mathrm{C}-8\left(\delta_{\mathrm{C}} 81.6\right)$ and C-9 $\left(\delta_{\mathrm{C}} 73.4\right)$ indicated the presence of a $2,3-$ dihydroxy-3-methyl-butyl moiety in compound 2 (Fig. 4). The attachment of this moiety to a meta-coupled benzene ring at the C-6 position was confirmed by the HMBC correlations from $\mathrm{H}^{-}$ $7 \mathrm{a}$ and $\mathrm{H}-7 \mathrm{~b}$ to $\mathrm{C}-1\left(\delta_{\mathrm{C}} 129.8\right), \mathrm{C}-5\left(\delta_{\mathrm{C}} 117.0\right)$ and C-6 $\left(\delta_{\mathrm{C}} 132.6\right)$, from $\mathrm{H}-3$ to C-1, C-4 $\left(\delta_{\mathrm{C}} 155.0\right)$ and $\mathrm{C}-5$, and from $\mathrm{H}-5$ to $\mathrm{C}-1, \mathrm{C}-3$ $\left(\delta_{\mathrm{C}} 112.8\right), \mathrm{C}-4$ and $\mathrm{C}-7\left(\delta_{\mathrm{C}} 35.1\right) . \mathrm{C}-4$ was suggested to be substituted with a hydroxy group due to its high chemical shift. The HMBC correlations from $\mathrm{H}-2^{\prime} \mathrm{a}$ and $\mathrm{H}-2^{\prime} \mathrm{b}$ to $\mathrm{C}-2\left(\delta_{\mathrm{C}} 124.4\right)$

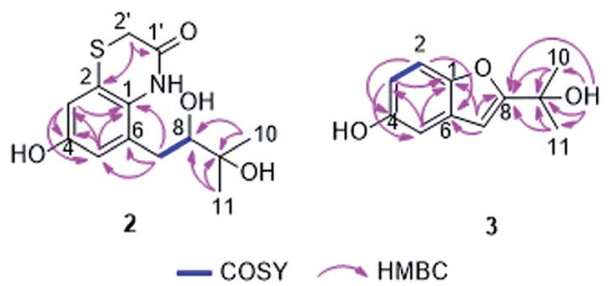

Fig. 4 Key COSY and HMBC correlations of compounds 2 and 3. and $\mathrm{C}-1^{\prime}\left(\delta_{\mathrm{C}}\right.$ 167.6), combined with its molecular formula, indicated that the isolated methylene $\mathrm{CH}_{2}-2^{\prime}$ was linked to the benzene ring via an amide bond and a sulfur atom at the C-1 and C-2 positions to form an additional ring. Thus, the structure of $\mathbf{2}$ was determined, representing a rare sulfur-containing alkaloid, of which the co-isolated known hydroquinone derivative $\mathrm{F}-11334 \mathrm{~A}_{1}$ (13) could be the precursor.

Gliomastin C (3) was recovered as a white amorphous powder, possessing the molecular formula $\mathrm{C}_{11} \mathrm{H}_{12} \mathrm{O}_{3}$ as determined by HRESIMS. Its ${ }^{1} \mathrm{H}$ NMR data (Table 2) exhibited three aromatic protons at $\delta_{\mathrm{H}} 7.25(\mathrm{~d}, J=8.8 \mathrm{~Hz}, \mathrm{H}-2), 6.95(\mathrm{~d}, J=$ $2.5 \mathrm{~Hz}, \mathrm{H}-5)$ and $6.76(\mathrm{dd}, J=8.8,2.5 \mathrm{~Hz}, \mathrm{H}-3)$, which are characteristic signals of an ABX ring system. Together with the HMBC correlations from $\mathrm{H}-2$ to $\mathrm{C}-4\left(\delta_{\mathrm{C}} 154.1\right)$ and C- $6\left(\delta_{\mathrm{C}} 130.3\right)$, from $\mathrm{H}-3$ to $\mathrm{C}-1\left(\delta_{\mathrm{C}} 149.9\right)$ and $\mathrm{C}-5\left(\delta_{\mathrm{C}} 106.4\right)$, and from $\mathrm{H}-5$ to $\mathrm{C}-$ 1 and C-3 $\left(\delta_{\mathrm{C}} 113.0\right)$, a benzene ring in 3 was established (Fig. 4). Furthermore, the HMBC correlations from Me-10/11 to C-8 $\left(\delta_{\mathrm{C}}\right.$ 166.3) and C-9 $\left(\delta_{\mathrm{C}} 69.1\right)$, from OH-9 $\left(\delta_{\mathrm{H}} 4.32\right)$ to C-8, C-9 and C$10 / 11\left(\delta_{\mathrm{C}} 29.4\right)$, and from $\mathrm{H}-7\left(\delta_{\mathrm{H}} 6.52\right.$, s) to C-1, C-6 and C-8 indicated the nature of a 3-hydroxy-3-methyl-butenyl moiety and its attachment to C-6. A hydroxy group at C-4 and an oxygen bridge between C-1 and C-8 were assigned in consideration of the molecular formula and the chemical shifts of the corresponding carbons. Thus, the structure of gliomastin C (3) was elucidated as shown.

Gliomastin D (4) shared the same molecular formula as gliomastin C (3). The UV spectra and NMR data (Table 2) of 4 were also comparable to those of 3 . Three aromatic protons belonging to an ABX coupling system at $\delta_{\mathrm{H}} 7.29(\mathrm{~d}, \mathrm{H}-2), 6.98(\mathrm{~d}$, $\mathrm{H}-5)$ and 6.80 (dd, $\mathrm{H}-3)$ were found in addition to a singlet olefinic methine at $\delta_{\mathrm{H}} 6.63(\mathrm{H}-7)$ and two singlet methyls at $\delta_{\mathrm{H}}$ 1.55 (Me-10 and 11). Analysis of the 1D and 2D NMR spectra of 4 revealed that the two compounds were structurally similar except for the position of the hydroxy group and the oxygen bridge. The upfield shifted C-8 $(-4.4 \mathrm{ppm})$ and downfield shifted C-9 (+4.7 ppm) in 4 compared to those of 3 suggested the

Table 2 NMR data for compounds 3-5

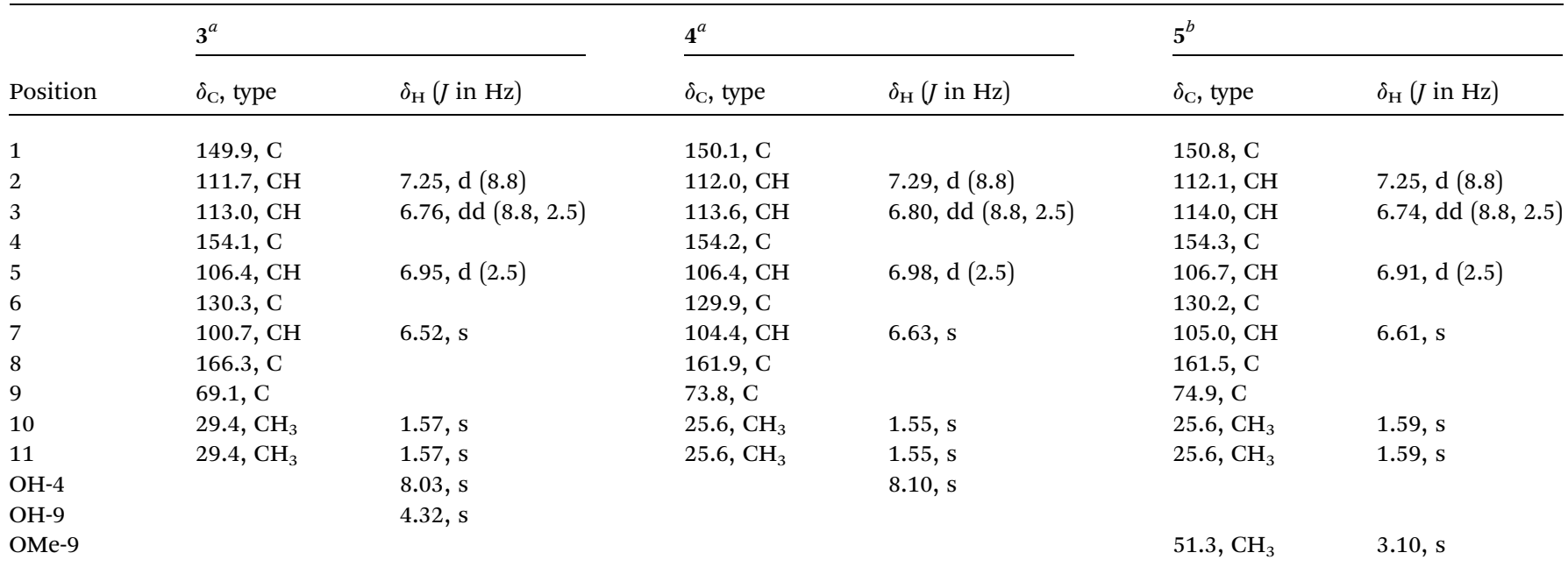

${ }^{a}$ Recorded at $600 \mathrm{MHz}$ for ${ }^{1} \mathrm{H}$ and $150 \mathrm{MHz}$ for ${ }^{13} \mathrm{C}_{\text {in }} \mathrm{CD}_{3} \mathrm{COCD}_{3} \cdot{ }^{b}$ Recorded at $600 \mathrm{MHz}$ for ${ }^{1} \mathrm{H}$ and $150 \mathrm{MHz}$ for ${ }^{13} \mathrm{C}$ in $\mathrm{CD}_{3} \mathrm{OD}$. 
presence of a pyran ring and a hydroxy group at C-8 in $\mathbf{4}$ instead of a furan ring.

Compound 5 was isolated as a white amorphous powder with the molecular formula $\mathrm{C}_{12} \mathrm{H}_{14} \mathrm{O}_{3}$ as established by HRESIMS, containing an additional $\mathrm{CH}_{2}$ unit compared to gliomastin $\mathrm{C}$ (3). The UV absorption spectrum and NMR data (Table 2) of 5 resembled those of 3 except for the appearance of an additional methoxy group at $\delta_{\mathrm{C}} 51.3$ and $\delta_{\mathrm{H}} 3.10$, which was further confirmed to be located at C- 9 by the HMBC correlation from the protons of the methoxy group to $\mathrm{C}-8\left(\delta_{\mathrm{C}} 74.9\right)$. Thus, compound 5 was elucidated as 9-O-methylgliomastin $\mathrm{C}$.

The HRESIMS of compound $\mathbf{6}$ displayed a pseudomolecular ion peak at $m / z 361.1255[\mathrm{M}+\mathrm{Na}]^{+}$, corresponding to the molecular formula $\mathrm{C}_{17} \mathrm{H}_{22} \mathrm{O}_{7}$. Positive and negative ESIMS showed fragment peaks at $m / z 177[\mathrm{M}+\mathrm{H}-162]^{+}$and $175[\mathrm{M}-$ $\mathrm{H}-162]^{+}$, respectively, which suggested the presence of a hexose residue in the molecule. The UV and NMR data (Table 3) of 6 were similar to those of acremonin A 4-O- $\beta$-Dglucopyranoside. ${ }^{24}$ Acid hydrolysis of 6 yielded two products, one of which was confirmed to be the co-isolated hydroquinone acremonin A (11) by comparison of their NMR data and optical rotation values. ${ }^{24}$ The other product was determined as $\beta$-Dglucopyranose by TLC analysis and optical rotation measurement compared to a known standard as well as by the $J$ value $(7.7 \mathrm{~Hz})$ of the anomeric proton $\left(\mathrm{H}-1^{\prime}\right)$ in 6 . Along with the $1 \mathrm{D}$ and 2D NMR spectra, compound 6 was unambiguously determined to contain an acremonin A moiety and a glucopyranose residue (Fig. 5). However, the HMBC correlations from $\mathrm{H}-1^{\prime}\left(\delta_{\mathrm{H}}\right.$ $4.88, \mathrm{~d})$ to $\mathrm{C}-1\left(\delta_{\mathrm{C}} 146.6\right)$ rather than to $\mathrm{C}-4\left(\delta_{\mathrm{C}} 147.2\right)$ indicated
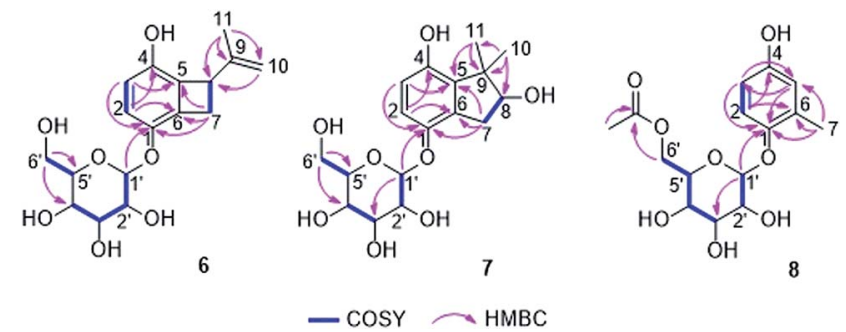

Fig. 5 Key COSY and HMBC correlations of compounds 6, 7 and 8 .

that the glucopyranose residue was attached to $\mathrm{C}-1$ instead of $\mathrm{C}$ 4. Thus compound 6 was elucidated as acremonin A 1-O- $\beta$-Dglucopyranoside.

Since the absolute configuration of acremonin A (11) is unknown in literature, ECD calculations were carried out for the arbitrarily chosen $(S)$ enantiomer of the aglycone 11. DFT reoptimization of the initial $15 \mathrm{MMFF}$ conformers yielded 8 lowenergy conformers at both the B3LYP/6-31G(d) in vacuo and the B97D/TZVP PCM/MeCN levels of theory. ECD spectra computed at various levels for these conformers gave nice mirror-image agreement with the experimental spectrum (Fig. 6). In some of the higher-energy conformers (e.g. conformers C and D, Fig. 7), the isopropenyl adopted a different orientation from that of the lowest-energy conformer, which is reflected in a near mirror image ECD of the conformers. Considering the relatively small computed energy differences of the conformers, this might be a possible source of error (energy difference between conformers A and $\mathrm{C}$ is less than $\left.1 \mathrm{~kJ} \mathrm{~mol}^{-1}\right){ }^{18,21}$ Therefore OR

Table 3 NMR data for compounds 6-8

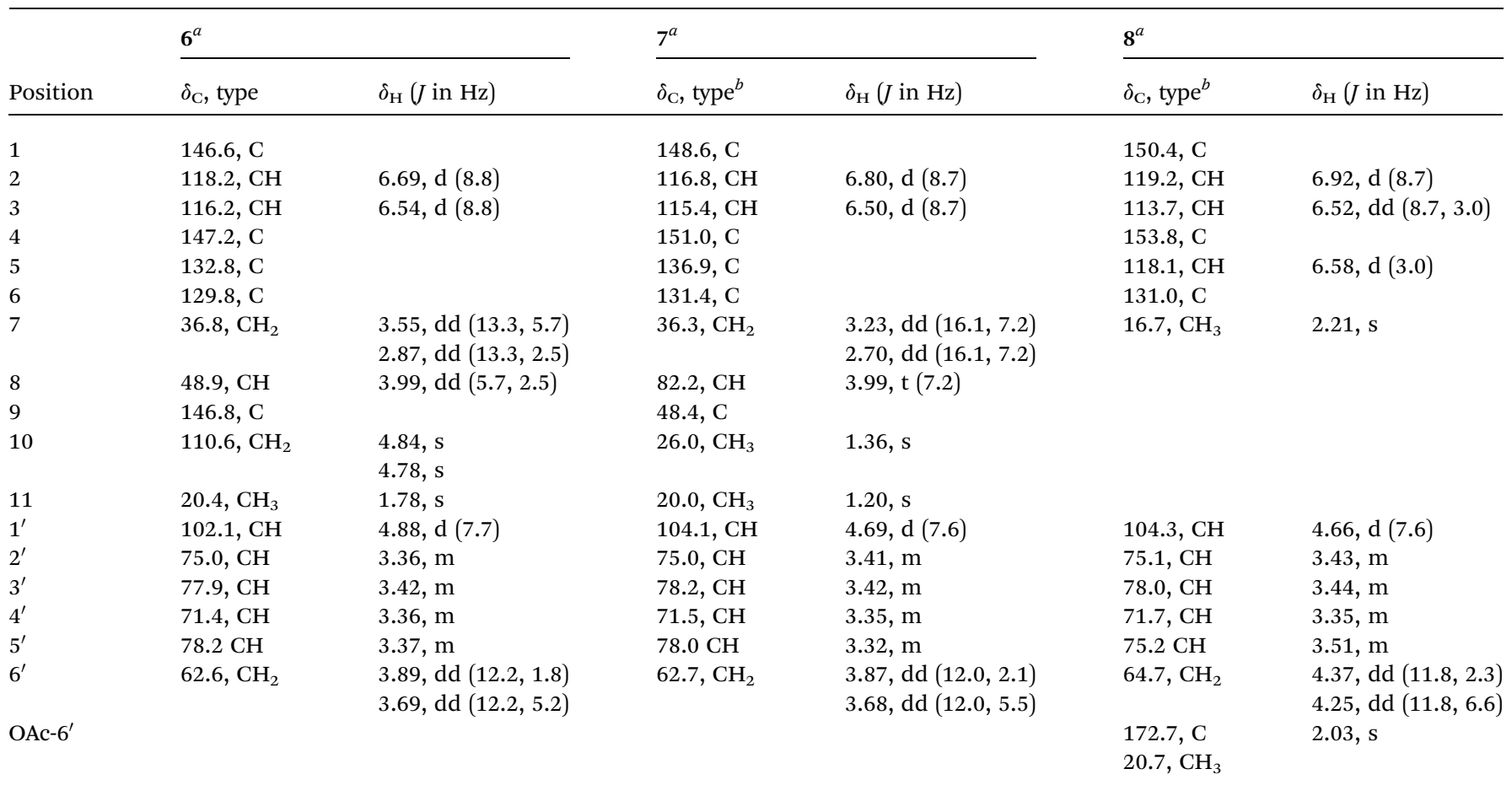

\footnotetext{
${ }^{a}$ Recorded at $600 \mathrm{MHz}$ for ${ }^{1} \mathrm{H}$ and $150 \mathrm{MHz}$ for ${ }^{13} \mathrm{C}$ in $\mathrm{CD}_{3} \mathrm{OD} .{ }^{b}$ Data extracted from HSQC and HMBC spectra.
} 


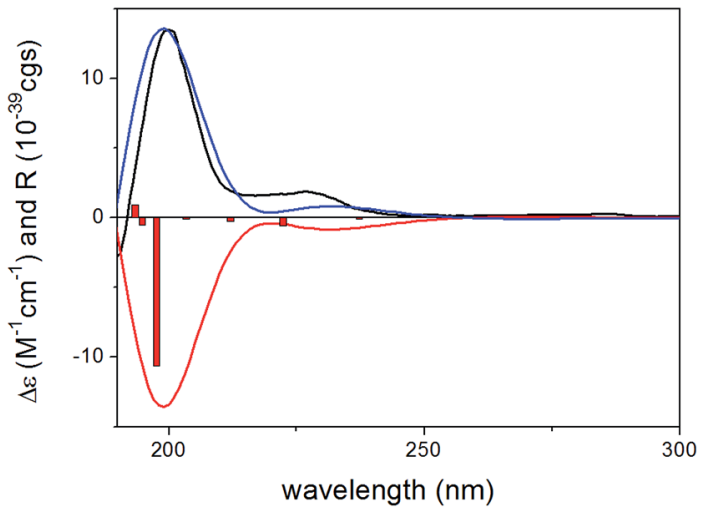

Fig. 6 Experimental ECD spectrum of 11 in $\mathrm{MeCN}$ (black line) compared with the PBEO/TZVP PCM/MeCN ECD spectra computed for the B97D/TZVP PCM/MeCN optimized low-energy conformers of (S)-11 (average of 8 conformers/2, red line) and $(R)$-11 (average of 8 conformers $/ 2$, blue line). Bars represent computed rotational strength values of $(S)$-11 (conformer $A / 2$ ).

calculations were also performed on the low-energy gas-phase conformers and on those reoptimized at the B97D/TZVP PCM/ $\mathrm{MeOH}$ level (8 conformers over $2 \%$ also at this level) ${ }^{27,28}$ The OR calculations performed at various levels for both sets of conformers were in line with the ECD results confirming the previous assignment. However, the sign of the OR values of the individual conformers were influenced by the orientation of isopropenyl group such as in the case of ECD. The $(R)$ absolute configuration of the calculations was also confirmed by the biosynthetic relationship of $\mathbf{1}$ and $\mathbf{1 1}$.

Compound 7 was obtained as a white solid. It possesses the molecular formula $\mathrm{C}_{17} \mathrm{H}_{24} \mathrm{O}_{8}$ as established by analysis of the HRESIMS data. Similar to 6, the NMR data (Table 3) of 7 exhibited two ortho-coupled aromatic protons at $6.80 \mathrm{~d}, J=$ $8.7 \mathrm{~Hz}, \mathrm{H}-2)$ and $6.50(\mathrm{~d}, J=8.7 \mathrm{~Hz}, \mathrm{H}-3)$, signals of a methylene group at $\delta_{\mathrm{H}} 3.23(\mathrm{dd}, J=16.1,7.2 \mathrm{~Hz}, \mathrm{H}-7 \mathrm{a})$ and $2.70(\mathrm{dd}, J=$ $16.1,7.2 \mathrm{~Hz}, \mathrm{H}-7 \mathrm{~b}$ ) and signals of a hexose residue including an anomeric proton at $4.69\left(\mathrm{~d}, J=7.6 \mathrm{~Hz}, \mathrm{H}-1^{\prime}\right)$. The nature of the benzene ring was established by the $\mathrm{HMBC}$ correlations from $\mathrm{H}$ 2 to $\mathrm{C}-4\left(\delta_{\mathrm{C}} 151.0\right)$ and $\mathrm{C}-6\left(\delta_{\mathrm{C}} 131.4\right)$ and from $\mathrm{H}-3$ to $\mathrm{C}-1\left(\delta_{\mathrm{C}}\right.$ 148.6) and $\mathrm{C}-5\left(\delta_{\mathrm{C}}\right.$ 136.9) (Fig. 5). Analysis of the hydrolysis products of 7 confirmed the presence of a glucopyranose residue, which was determined to be attached to $\mathrm{C}-1$ by the HMBC correlation from $\mathrm{H}^{-1} \mathbf{1}^{\prime}$ to $\mathrm{C}-1$. However, compared to $\mathbf{6}$, the signals of the isopropenyl group were replaced by two singlet methyl groups at $\delta_{\mathrm{H}} 1.35(\mathrm{~s}, \mathrm{Me}-10)$ and $1.20(\mathrm{~s}, \mathrm{Me}-11)$ as well as by an oxygenated methine at $\delta_{\mathrm{C}} 82.2$ and $\delta_{\mathrm{H}} 3.99(\mathrm{CH}-8)$. The COSY correlations between $\mathrm{H}-7 \mathrm{a} / \mathrm{H}-8$ and $\mathrm{H}-7 \mathrm{~b} / \mathrm{H}-8$ together with the HMBC correlations from Me-10 and Me-11 to $\mathrm{C}-5, \mathrm{C}-8$ and $\mathrm{C}-9\left(\delta_{\mathrm{C}} 48.4\right)$, and from $\mathrm{H}-7 \mathrm{a}$ and $\mathrm{H}-7 \mathrm{~b}$ to $\mathrm{C}-1$, C-5 and C-6 indicated the presence of a further cyclopentene ring with two methyls at C-9 and a hydroxy group at C-8, which was fused to the benzene ring. Thus, the structure of 7 was elucidated as shown. Its aglycone was obtained following hydrolysis of 7 , representing a new hydroquinone derivative, for which the name gliomastin $\mathrm{E}$ is proposed.

For the configurational assignment of the aglycone gliomastin E, the solution TDDFT-ECD calculation protocol was carried out on the arbitrarily chosen $(S)$ enantiomer. Reoptimization of the initial $23 \mathrm{MMFF}$ conformers resulted in 13 and 15 low-energy ( $\geq 2 \%$ ) conformers at the B3LYP/6-31G(d) in vacuo and the B97D/TZVP PCM/MeCN levels. ECD spectra computed at various levels for both sets of conformers resembled the 247 and the $198 \mathrm{~nm}$ transitions of gliomastin E suggesting $(S)$ absolute configuration (Fig. 8). Since the $273 \mathrm{~nm}$ positive Cotton effect (CE) could not be reproduced by any of the applied combination, OR calculations performed in vacuo and in $\mathrm{MeOH}$ (similarly to 11) were applied to prove the $(S)$ absolute configuration. ${ }^{28}$ OR values computed at all of the applied combinations of levels resulted in small positive overall optical rotations in the range from +10.2 to +18.4 , while the experimental value was +15.2 , which verified the ECD results.

The molecular formula $\mathrm{C}_{15} \mathrm{H}_{20} \mathrm{O}_{8}$ was deduced for compound $\mathbf{8}$ from the HRESIMS data. The UV spectrum and

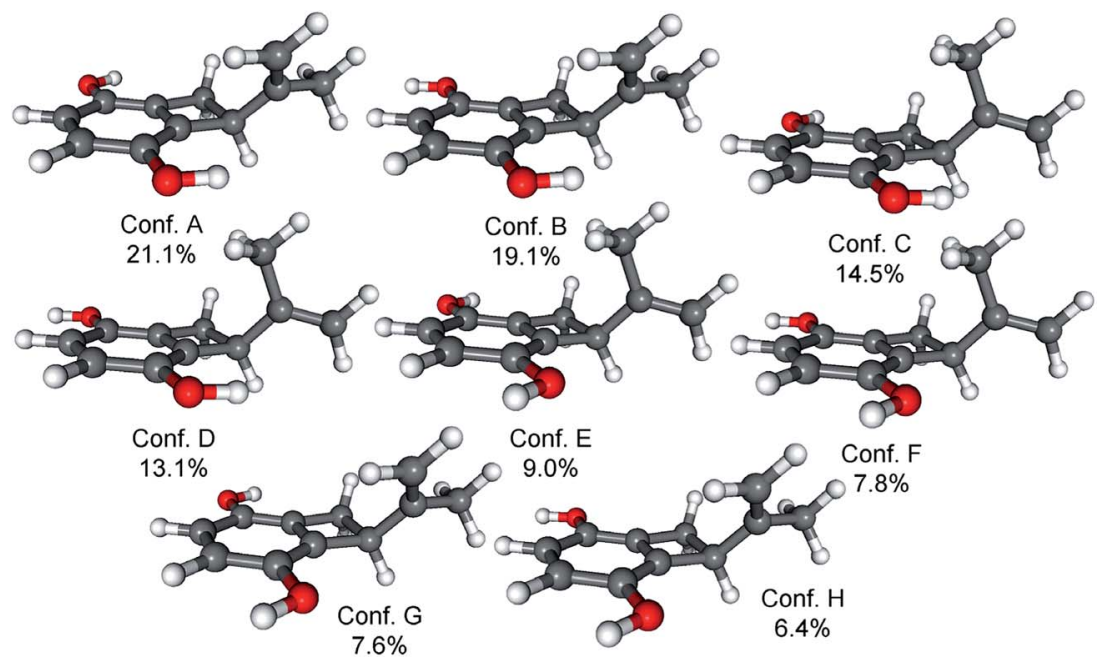

Fig. 7 Structures and populations of the low-energy ( $\geq 2 \%)$ B97D/TZVP PCM/MeCN conformers of (S)-11. 


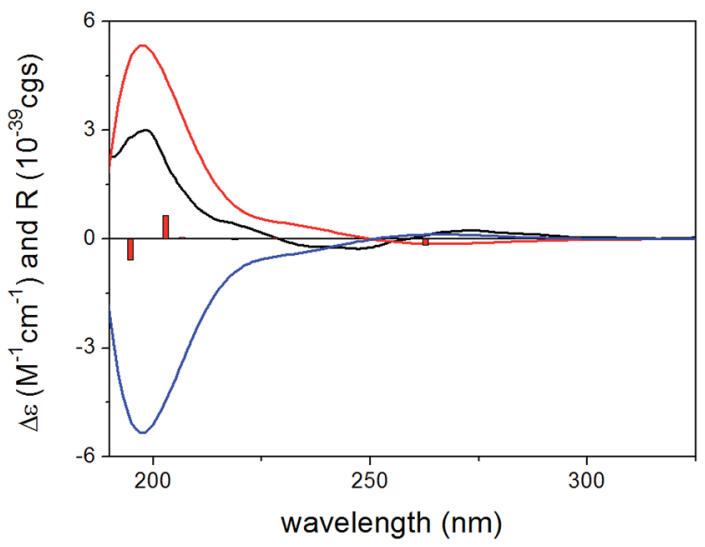

Fig. 8 Experimental ECD spectrum of gliomastin $\mathrm{E}$ in $\mathrm{MeCN}$ (black line) compared with the B3LYP/TZVP ECD spectra computed for the $B 3 L Y P / 6-31 G(d)$ in vacuo optimized low-energy conformers of $(S)$ gliomastin $\mathrm{E}$ (average of 13 conformers, red line) and $(R)$-gliomastin $\mathrm{E}$ (average of 13 conformers, blue line). Bars represent computed rotational strength values of the lowest-energy conformer of (S)-gliomastin $\mathrm{E}$.

NMR data (Table 3) of $\mathbf{8}$ were almost identical to those of isohomoarbutin (9), ${ }^{29,30}$ except for the appearance of an additional acetoxy group $\left(\delta_{\mathrm{H}} 2.03, \delta_{\mathrm{C}} 20.7\right.$ and 172.7) in 8. This acetoxy group was determined to be located at C-6 ${ }^{\prime}$ on the basis of the HMBC correlations from $\mathrm{H}-6^{\prime} \mathrm{a}$ and $\mathrm{H}-6^{\prime} \mathrm{b}\left(\delta_{\mathrm{H}} 4.37\right.$ and 4.25$)$ to the carbonyl carbon of the acetoxy group. The remaining structure of $\mathbf{8}$ was confirmed to be the same as $\mathbf{9}$ by detailed analysis of the 2D NMR spectra of 8 (Fig. 5). The hexose residue was determined to be $\beta$-D-glucopyranose by the coupling constant $(7.6 \mathrm{~Hz})$ of the anomeric proton $\left(\mathrm{H}-\mathrm{1}^{\prime}\right)$ and analysis of the acid hydrolysis products of $\mathbf{8}$ in comparison with a known standard. Owing to the data mentioned above, compound 8 was elucidated as 6'-O-acetyl-isohomoarbutin.

By comparison with the literature data, the remaining known compounds were identified as isohomoarbutin (9), ${ }^{29,30} 2$ methyl-1,4-benzenediol (10), ${ }^{31}$ acremonin A (11), ${ }^{24}$ prenylhydroquinone (12), ${ }^{32,33} \mathrm{~F}-11334 \mathrm{~A}_{1}(13),{ }^{25,26}(R)$-2-(2-hydroxypropan2-yl)-2,3-dihydro-5-hydroxybenzofuran (14), ${ }^{34}$ and 2,2-dimethylchroman-3,6-diol (15). ${ }^{24}$
All isolated compounds (1-15) were evaluated for their cytotoxicity against the L5178Y murine lymphoma cell line (Table 4). Compounds 1, 10, 12 and 13 showed significant cytotoxic activity with $\mathrm{IC}_{50}$ values of $1.8,1.0,1.1$ and $3.0 \mu \mathrm{M}$, respectively, which are below that of the positive control kahalalide F. Compared to the two precursors 11 and 13, compound 1 demonstrated stronger cytotoxicity while the sulfurcontaining alkaloid 2 was inactive compared to its precursor 13. Compounds 10 and 11 showed strong cytotoxicity while their glycosides 8, 9 and 6 were inactive. The ether bridge in 14 and $\mathbf{1 5}$ led to total loss of cytotoxicity compared to $\mathbf{1 3 .}$

In addition, all compounds were tested for their antitubercular activity against Mycobacterium tuberculosis and for their antibacterial activities against different strains of pathogenic bacteria (Table 4). Only compounds 10 and 12 exhibited antibacterial activity but they were also cytotoxic. Compound 3, which lacked cytotoxicity, showed antitubercular activity with a MIC value of $12.5 \mu \mathrm{M}$. Comparison of the antitubercular activity of 3 with those of $4,5,14$ and 15 indicated the importance of the furan ring and of the free hydroxy group at C-9.

In conclusion, our investigation of secondary metabolites from the marine-derived fungus Gliomastix sp. led to the isolation of fifteen hydroquinone derivatives including eight new natural products (1-8). Among the latter, the dimer 1 possesses a novel carbon skeleton, which could be derived from derivatives of $\mathbf{1 1}$ and $\mathbf{1 3}$ through a Diels-Alder reaction. Compound 1 also exhibited significant cytotoxicity against the L5178Y mouse lymphoma cell line with an $\mathrm{IC}_{50}$ value of $1.8 \mu \mathrm{M}$. Compound 2 is a rare sulfur-containing alkaloid. TDDFT-ECD and OR calculations were performed to determine the absolute configurations of $\mathbf{1}$ and the aglycones of $\mathbf{6}$ and 7. All isolated compounds were tested for their cytotoxic and antimicrobial activity and the structure-activity relationships were discussed.

\section{Experimental section}

\section{General procedures}

Optical rotations were recorded on a PerkinElmer-241 MC polarimeter. ${ }^{1} \mathrm{H},{ }^{13} \mathrm{C}$ and $2 \mathrm{D}$ NMR spectra were measured on a Bruker Avance DMX 600 NMR spectrometer. A Finnigan LCQ

Table 4 Cytotoxicity, antitubercular and antibacterial activities of 1, 3, 10-13

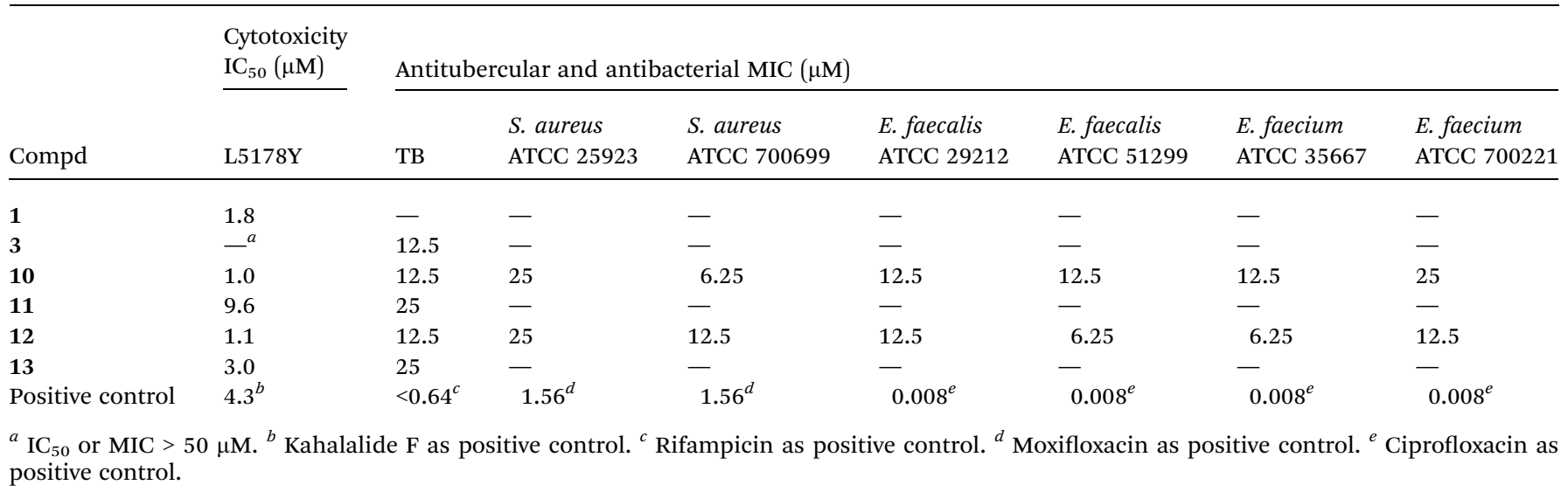


Deca XP Thermoquest spectrometer was used to record mass spectra while a FTHRMS-Orbitrap (Thermo Finnigan) mass spectrometer was utilized to obtain HRESIMS data. The Dionex P580 HPLC system was coupled to a photodiode array detector (UVD340S) and the analytical column $(125 \times 4 \mathrm{~mm}$, L x i.d.) was prefilled with Eurospher-10 $\mathrm{C}_{18}$ (Knauer, Germany). Semipreparative HPLC separation was performed on a LachromMerck Hitachi HPLC system (Pump L7100, UV detector L7400 and Eurosphere $100 \mathrm{C}_{18}$ column: $300 \times 8 \mathrm{~mm}$ ) with $5.0 \mathrm{~mL}$ $\min ^{-1}$ flow rate. Normal phase column chromatography was carried out using Merck MN Silica gel $60 \mathrm{M}(0.04-0.063 \mathrm{~mm})$ or Sephadex LH-20. TLC was carried out on precoated Silica Gel 60 F254 plates (Merck, Germany) with UV detection at 254 and $365 \mathrm{~nm}$ as well as following spraying with anisaldehyde reagent or with methanol-sulfuric acid (95:5).

\section{Fungal material and identification}

The hard coral Stylophora sp. was obtained from the Red Sea in Egypt near the coastline of Ain El-Sokhna area in November 2012. The fungal strain was isolated from the freshly crushed inner tissues of the coral following standard procedures and was identified as Gliomastix sp. according to a molecular biological protocol that was carried out through DNA amplification and sequencing of ITS region as described previously. ${ }^{9,35}$ The obtained data of sequencing were submitted to GenBank with the accession number KX354951. A voucher strain was deposited in the Institute of Pharmaceutical Biology and Biotechnology, Heinrich-Heine University, Düsseldorf, Germany, with the ID code ST-F3.

\section{Cultivation, extraction and isolation}

Fungal biomass fermentation was performed in Erlenmeyer flasks $(15 \times 1 \mathrm{~L}$, each contains $100 \mathrm{~g}$ rice of commercially available rice and $110 \mathrm{~mL}$ water, which was kept overnight before being autoclaved for $20 \mathrm{~min}$ at a temperature of $121^{\circ} \mathrm{C}$ ) on solid rice medium at $25{ }^{\circ} \mathrm{C}$ under static conditions for $30 \mathrm{~d}$. Harvesting process started with soaking the culture of each flask in EtOAc $(500 \mathrm{~mL})$, in addition to cutting the culture mass into small pieces using a spatula. The flasks were then kept overnight and subjected to shaking at $150 \mathrm{rpm}$ for $8 \mathrm{~h}$ on the next day. The obtained extract was subjected to filtration, and evaporated to obtain a dark brown crude extract $(6.5 \mathrm{~g})$.

This crude extract was partitioned between $n$-hexane and $90 \%$ aqueous methanol and the resulting methanolic phase was evaporated to give $4.5 \mathrm{~g}$ of methanolic extract, which was further chromatographed over silica gel using vacuum liquid chromatography (VLC). Gradient elution with $n$-hexane-EtOAc (100:0 to $0: 100)$ and $\mathrm{CH}_{2} \mathrm{Cl}_{2}-\mathrm{MeOH}(100: 0$ to $0: 100)$ was used and $500 \mathrm{~mL}$ eluting volume for each fraction was collected to obtain fifteen subfractions (F1-F15).

F4 $(750 \mathrm{mg})$ was subjected to a Sephadex LH-20 $(100 \times 5 \mathrm{~cm})$ column using $\mathrm{MeOH}$ as eluent to obtain six subfractions (F4-1F4-6), of which F4-5 (80 mg) was purified using semi-preparative RP-HPLC with $60 \% \mathrm{MeOH}-\mathrm{H}_{2} \mathrm{O}$ as mobile phase to yield compounds 10 (42.3 mg), 11 (3.6 mg) and 12 (13.0 mg).
F5 (120 mg) was further fractionated using a Sephadex LH-20 column $(80 \times 4 \mathrm{~cm})$ with $\mathrm{MeOH}$ as eluent to give five subfractions (F5-1-F5-5). Subfraction F5-1 (34 mg) was subjected to semi-preparative RP-HPLC with $38 \% \mathrm{MeOH}-\mathrm{H}_{2} \mathrm{O}$ to yield 15 (14.0 mg) and 14 (3.2 mg). Subfraction F5-2 (14 mg) was purified by semi-preparative RP-HPLC using $50 \% \mathrm{MeOH}-\mathrm{H}_{2} \mathrm{O}$ to give 5 (1.5 mg). Subfraction F5-3 (10 mg) was separated by semipreparative RP-HPLC using $57 \% \mathrm{MeOH}-\mathrm{H}_{2} \mathrm{O}$ to afford 3 (0.9 $\mathrm{mg}$ ) and 4 (2.4 mg). Subfraction F5-4 (15 mg) was purified by semi-preparative RP-HPLC with $64 \% \mathrm{MeOH}-\mathrm{H}_{2} \mathrm{O}$ as mobile phase to yield 1 (3.5 $\mathrm{mg}$ ).

Following similar procedures, compound $\mathbf{1 3}(7.4 \mathrm{mg})$ was obtained from fraction F8, by column chromatography over a Sephadex LH-20 column $(100 \times 5 \mathrm{~cm})$ with $\mathrm{MeOH}$ as eluent, followed by purification using semipreparative RP-HPLC with $34 \% \mathrm{MeOH}-\mathrm{H}_{2} \mathrm{O}$.

F10 (235 mg) was separated into five subfractions (F10-1F10-5) by a Sephadex LH-20 column $(80 \times 4 \mathrm{~cm})$ using $100 \%$ $\mathrm{MeOH}$ as eluent. Subfraction F10-3 (35 mg) was then subjected to semi-preparative RP-HPLC eluted with $40 \% \mathrm{MeOH}-\mathrm{H}_{2} \mathrm{O}$ to yield 9 (1.8 mg) and 8 (3.0 mg) while subfraction F10-4 (13 mg) was purified by semi-preparative RP-HPLC with $50 \% \mathrm{MeOH}-$ $\mathrm{H}_{2} \mathrm{O}$ to afford $2(0.8 \mathrm{mg})$.

Compounds $7(2.2 \mathrm{mg})$ and $6(3.0 \mathrm{mg})$ were obtained from fraction F12 $(150 \mathrm{mg})$ using a Sephadex LH-20 column $(80 \times 4$ $\mathrm{cm}$ ) with $\mathrm{MeOH}$ for elution followed by semi-preparative HPLC separation with $35 \% \mathrm{MeOH}-\mathrm{H}_{2} \mathrm{O}$ as eluent.

Gliomastin A (1). Yellow amorphous powder; $[\alpha]_{\mathrm{D}}{ }^{20}-6(c$ 0.37, MeOH); UV (MeOH) $\lambda_{\text {max }}: 212$ and $296 \mathrm{~nm}$; ECD $\{\mathrm{MeCN}$, $\left.\lambda_{\max }(\Delta \varepsilon) c 0.35 \mathrm{mM}\right\} 392(+0.46), 372 \mathrm{sh}(+0.34), 331(-0.18)$, 272sh (+0.27), $255(+0.60), 228 \mathrm{sh}(-2.88), 215 \mathrm{sh}(-3.75), 197$ $(-7.91) \mathrm{nm} ;{ }^{1} \mathrm{H}$ NMR and ${ }^{13} \mathrm{C}$ NMR data, see Table 1 ; HRESIMS $[\mathrm{M}+\mathrm{Na}]^{+} \mathrm{m} / z$ 373.1412 (calcd for $\mathrm{C}_{22} \mathrm{H}_{22} \mathrm{O}_{4} \mathrm{Na}, 373.1410$ ).

Gliomastin B (2). White solid; $[\alpha]_{\mathrm{D}}{ }^{20}+24(c 0.08, \mathrm{MeOH})$; UV (MeOH) $\lambda_{\text {max }}: 211,243$ and $292 \mathrm{~nm} ;{ }^{1} \mathrm{H}$ NMR and ${ }^{13} \mathrm{C}$ NMR data, see Table 1; HRESIMS $[\mathrm{M}+\mathrm{H}]^{+} \mathrm{m} / z 284.0950$ (calcd for $\mathrm{C}_{13} \mathrm{H}_{18} \mathrm{NO}_{4} \mathrm{~S}, 284.0951$ ).

Gliomastin C (3). White amorphous powder; UV (MeOH) $\lambda_{\text {max }}: 203,249$ and $294 \mathrm{~nm} ;{ }^{1} \mathrm{H}$ NMR and ${ }^{13} \mathrm{C}$ NMR data, see Table 2; HRESIMS $[\mathrm{M}+\mathrm{Na}]^{+} \mathrm{m} / z \quad 215.0677$ (calcd for $\mathrm{C}_{11} \mathrm{H}_{12} \mathrm{O}_{3} \mathrm{Na}$, 215.0679).

Gliomastin D (4). White amorphous powder; UV (MeOH) $\lambda_{\max }: 206,249$ and $295 \mathrm{~nm} ;{ }^{1} \mathrm{H}$ NMR and ${ }^{13} \mathrm{C}$ NMR data, see Table 2; HRESIMS $\left[\mathrm{M}-\mathrm{H}_{2} \mathrm{O}+\mathrm{H}\right]^{+} m / z 175.0751$ (calcd for $\mathrm{C}_{11} \mathrm{H}_{11} \mathrm{O}_{2}$, 175.0754).

9-O-Methylgliomastin C (5). White amorphous powder; UV $(\mathrm{MeOH}) \lambda_{\text {max }}: 206,249$ and $295 \mathrm{~nm} ;{ }^{1} \mathrm{H}$ NMR and ${ }^{13} \mathrm{C}$ NMR data, see Table 2; HRESIMS [M $-\mathrm{H}]^{-} m / z 205.0870$ (calcd for $\left.\mathrm{C}_{12} \mathrm{H}_{13} \mathrm{O}_{3}, 205.0870\right)$.

Acremonin A 1-O- $\boldsymbol{\beta}$-D-glucopyranoside (6). White amorphous powder; $[\alpha]_{\mathrm{D}}{ }^{20}+30(c 0.31, \mathrm{MeOH}) ; \mathrm{UV}(\mathrm{MeOH}) \lambda_{\max }: 206$ and $298 \mathrm{~nm}$; ${ }^{1} \mathrm{H}$ NMR and ${ }^{13} \mathrm{C}$ NMR data, see Table 3; HRESIMS $[\mathrm{M}+\mathrm{Na}]^{+} m / z 361.1255$ (calcd for $\mathrm{C}_{17} \mathrm{H}_{22} \mathrm{O}_{7} \mathrm{Na}, 361.1258$ ).

Gliomastin E 1- $\boldsymbol{O}$ - $\boldsymbol{\beta}$-D-glucopyranoside (7). White solid; $[\alpha]_{\mathrm{D}}{ }^{20}$ +22 (c 0.33, MeOH); UV (MeOH) $\lambda_{\max }: 201$ and $281 \mathrm{~nm} ;{ }^{1} \mathrm{H}$ NMR and ${ }^{13} \mathrm{C}$ NMR data, see Table 3 ; HRESIMS $[\mathrm{M}+\mathrm{Na}]^{+} \mathrm{m} / \mathrm{z}$ 379.1361 (calcd for $\mathrm{C}_{17} \mathrm{H}_{24} \mathrm{O}_{8} \mathrm{Na}, 379.1363$ ). 
6'-O-Acetyl-isohomoarbutin (8). White amorphous powder; $[\alpha]_{\mathrm{D}}{ }^{20}+10\left(c\right.$ 0.31, MeOH); UV $(\mathrm{MeOH}) \lambda_{\max }: 201,214$ and $283 \mathrm{~nm} ;{ }^{1} \mathrm{H}$ NMR and ${ }^{13} \mathrm{C}$ NMR data, see Table 3; HRESIMS [M + $\mathrm{Na}]^{+} m / z 351.1053$ (calcd for $\mathrm{C}_{15} \mathrm{H}_{20} \mathrm{O}_{8} \mathrm{Na}, 351.1050$ ).

Acremonin A (11). $[\alpha]_{\mathrm{D}}{ }^{20}+138(c 0.37, \mathrm{MeOH})$; ECD $\{\mathrm{MeCN}$, $\left.\lambda_{\max }(\Delta \varepsilon) \quad c \quad 0.71 \mathrm{mM}\right\} 286 \mathrm{sh}(+0.30), 227 \mathrm{sh}(+1.90), 200$ $(+13.49) \mathrm{nm}$.

Gliomastin E (aglycone of 7$) \cdot[\alpha]_{\mathrm{D}}{ }^{20}+15(c 0.05, \mathrm{MeOH})$; ECD $\left\{\mathrm{MeCN}, \lambda_{\max }(\Delta \varepsilon) c 0.70 \mathrm{mM}\right\} 273(+0.24), 247(-0.26), 198$ $(+3.01) \mathrm{nm}$.

\section{Acid hydrolysis}

Compounds 6-8 (1 mg each) were separately hydrolyzed with 2 $\mathrm{N} \mathrm{HCl}(2.0 \mathrm{~mL})$ at $90^{\circ} \mathrm{C}$ for $4 \mathrm{~h}$. After cooling, the solution was partitioned with EtOAc $(3 \mathrm{~mL} \times 3)$ and $\mathrm{H}_{2} \mathrm{O}$. The EtOAc phase containing the aglycone was dried under reduced pressure. The water phase containing the sugar moiety, was then examined using TLC analysis with D-glucose as an authentic standard (Sigma-Aldrich, Germany). Two different eluting systems were used including DCM-MeOH- $\mathrm{H}_{2} \mathrm{O}(6: 4: 1)$ and EtOAc-MeOH$\mathrm{H}_{2} \mathrm{O}(10: 4: 1)$, along with methanol-sulphuric acid as spraying reagent.

\section{Cytotoxicity assay}

The MTT method was performed to test the cytotoxicity of the compounds against the L5178Y mouse lymphoma cell line (European Collection of Authenticated Cell Cultures, Catalogue No. 87111908) as described previously. ${ }^{36}$ Kahalalide F was used as positive control and media with $0.1 \%$ DMSO was used as negative control.

\section{Antibacterial assay}

The antibacterial assay was performed using the broth microdilution method. Following the recommendations of the Clinical and Laboratory Standards Institute (CLSI), the MIC values against $S$. aureus ATCC 25923, S. aureus ATCC 700699, E. faecalis ATCC 29212, E. faecalis ATCC 51299, E. faecium ATCC 35667, E. faecium ATCC 700221 and Mycobacterium tuberculosis strain H37Rv were determined. ${ }^{37}$ Moxifloxacin (for $S$. aureus strains), ciprofloxacin (for E. faecalis and E. faecium strains) and rifampicin (for Mycobacterium tuberculosis) were used as positive controls.

\section{Computational section}

Mixed torsional/low-frequency mode conformational searches were carried out by means of the Macromodel 9.9.223 software using the Merck Molecular Force Field (MMFF) with an implicit solvent model for $\mathrm{CHCl}_{3}{ }^{38}$ Geometry reoptimizations were carried out at the B3LYP/6-31G(d) level in vacuo, the B3LYP/6$31+\mathrm{G}(\mathrm{d}, \mathrm{p})$ level in vacuo, the B97D/TZVP ${ }^{20,21}$ and the CAMB3LYP/ TZVP $^{22,23}$ levels with the PCM solvent model for MeCN or $\mathrm{MeOH}$. TDDFT ECD calculations and OR calculations were run with various functionals (B3LYP, BH\&HLYP, CAM-B3LYP, PBE0) and the TZVP basis set as implemented in the Gaussian 09 package with the same or no solvent model as in the preceding DFT optimization step. ${ }^{39}$ NMR calculations were performed at the mPW1PW91/6-311+G(2d,p) level. ${ }^{17}$ ECD spectra were generated as sums of Gaussians with 3000 and $3300 \mathrm{~cm}^{-1}$ widths at halfheight (corresponding to ca. 12 and $13 \mathrm{~nm}$ at $200 \mathrm{~nm}$ ), using dipole-velocity-computed rotational strength values. ${ }^{\mathbf{4 0}}$ Computed ECD spectra were shifted by -48 (B3LYP/TZVP for the B3LYP/6-31G(d) in vacuo conformers) for $1,+6$ (PBE0/TZVP $\mathrm{PCM} / \mathrm{MeCN}$ for the B97D/TZVP PCM/MeCN conformers) for $\mathbf{1 1}$ and -3 (B3LYP/TZVP for the B3LYP/6-31G(d) in vacuo conformers) for gliomastin E. Computed C-NMR data were corrected with $I=185.4855$ and $S=-1.0306$ and H-NMR data with $I=31.8996$ and $S=-1.0734 .^{41,42}$ Boltzmann distributions were estimated from the ZPVE-corrected B3LYP/6-31G(d) energies in the B3LYP/6-31G(d) gas-phase calculations, and from the uncorrected B3LYP/6-31+G(d,p), B97D/TZVP and CAM-B3LYP/ TZVP energies in the other cases. The MOLEKEL software package was used for visualization of the results. ${ }^{43}$

\section{Acknowledgements}

A scholarship granted and financed by the Egyptian government (Ministry of High Education) to M. S. E. is gratefully acknowledged. Financial support by the DFG (GRK 2158) to P. P. and R. K. is gratefully acknowledged. T. K. and A. M. thank the National Research, Development and Innovation Office (NKFI K120181 and PD121020) for financial support and the Governmental Information-Technology Development Agency (KIFÜ) for CPU time.

\section{Notes and references}

1 J. W. Blunt, B. R. Copp, R. A. Keyzers, M. H. G. Munro and M. R. Prinsep, Nat. Prod. Rep., 2014, 31, 160-258.

2 M. E. Rateb and R. Ebel, Nat. Prod. Rep., 2011, 28, 290-344.

3 X. M. Hou, R. F. Xu, Y. C. Gu, C. Y. Wang and C. L. Shao, Curr. Med. Chem., 2015, 22, 3707-3762.

4 T. A. Richards, M. D. M. Jones, G. Leonard and D. Bass, Annual Review of Marine Science, 2012, 4, 495-522.

5 W. Chen, Y. Li and Y. Guo, Acta Pharm. Sin. B, 2012, 2, 227237.

6 F. He, J. Bao, X. Y. Zhang, Z. C. Tu, Y. M. Shi and S. H. Qi, J. Nat. Prod., 2013, 76, 1182-1186.

7 C. J. Zheng, C. L. Shao, Z. Y. Guo, J. F. Chen, D. S. Deng, K. L. Yang, Y. Y. Chen, X. M. Fu, Z. G. She, Y. C. Lin and C. Y. Wang, J. Nat. Prod., 2012, 75, 189-197.

8 C. L. Shao, H. X. Wu, C. Y. Wang, Q. A. Liu, Y. Xu, M. Y. Wei, P. Y. Qian, Y. C. Gu, C. J. Zheng, Z. G. She and Y. C. Lin, J. Nat. Prod., 2011, 74, 629-633.

9 M. S. Elnaggar, S. S. Ebada, M. L. Ashour, W. Ebrahim, W. E. G. Müller, A. Mándi, T. Kurtán, A. Singab, W. Lin, Z. Liu and P. Proksch, Tetrahedron, 2016, 72, 2411-2419.

10 M. S. Elnaggar, S. S. Ebada, M. L. Ashour, W. Ebrahim, A. Singab, W. Lin, Z. Liu and P. Proksch, Fitoterapia, 2017, 116, 126-130.

11 W. Ebrahim, M. El-Neketi, L. I. Lewald, R. S. Orfali, W. Lin, N. Rehberg, R. Kalscheuer, G. Daletos and P. Proksch, J. Nat. Prod., 2016, 79, 914-922. 
12 S. Liu, H. Dai, G. Makhloufi, C. Heering, C. Janiak, R. Hartmann, A. Mándi, T. Kurtán, W. E. G. Müller, M. U. Kassack, W. Lin, Z. Liu and P. Proksch, J. Nat. Prod., 2016, 79, 2332-2340.

13 J. Zhang, X. P. Lin, L. C. Li, B. L. Zhong, X. J. Liao, Y. H. Liu and S. H. Xu, RSC Adv., 2015, 5, 54645-54648.

14 H. Y. Yang, D. Y. Niu, L. Wang, S. J. Wang, C. M. Zhang, X. M. Gao, G. Du and Q. F. Hu, J. Asian Nat. Prod. Res., 2015, 17, 319-323.

15 W. Dong, C. Liu, Q. Shen, T. Zhang, Y. Wang, K. Zhou, B. Ji, H. Yang, G. Du, Q. Hu and M. Zhou, Chem. Nat. Compd., 2016, 52, 620-623.

16 W. J. He, X. J. Zhou, X. C. Qin, Y. X. Mai, X. P. Lin, S. R. Liao, B. Yang, T. Zhang, Z. C. Tu, J. F. Wang and Y. Liu, Nat. Prod. Res., 2017, 31, 604-609.

17 C. Adamo and V. Barone, J. Chem. Phys., 1998, 108, 664-675. 18 G. Pescitelli and T. Bruhn, Chirality, 2016, 28, 466-474.

19 A. Mándi, I. W. Mudianta, T. Kurtán and M. J. Garson, J. Nat. Prod., 2015, 78, 2051-2056.

20 S. Grimme, J. Comput. Chem., 2006, 27, 1787-1799.

21 P. Sun, D. X. Xu, A. Mándi, T. Kurtán, T. J. Li, B. Schulz and W. Zhang, J. Org. Chem., 2013, 78, 7030-7047.

22 T. Yanai, D. Tew and N. Handy, Chem. Phys. Lett., 2004, 393, 51-57.

23 G. Pescitelli, L. Di Bari and N. Berova, Chem. Soc. Rev., 2011, 40, 4603-4625.

24 A. Abdel-Lateff, G. M. König, K. M. Fisch, U. Höller, P. G. Jones and A. D. Wright, J. Nat. Prod., 2002, 65, 16051611.

25 M. Tanaka, F. Nara, Y. Yamasato, Y. Ono and T. Ogita, J. Antibiot., 1999, 52, 827-830.

26 L. Shen, S. D. Zhao and H. J. Zhu, Gaodeng Xuexiao Huaxue Xuebao, 2011, 32, 2568-2573.

27 P. L. Polavarapu, Chirality, 2008, 20, 664-672.

28 P. Sun, Q. Yu, J. Li, R. Riccio, G. Lauro, G. Bifulco, T. Kurtán, A. Mándi, H. Tang, C. L. Zhuang, W. H. Gerwick and W. Zhang, J. Nat. Prod., 2016, 79, 2552-2558.

29 H. Thieme, Pharmazie, 1970, 25, 129.

30 E. Walewska and H. Thieme, Pharmazie, 1969, 24, 423.

31 H. M. Chawla, S. K. Sharma, K. Chakrabarty and S. Bhanumati, Tetrahedron, 1988, 44, 1227-1234.

32 Y. C. Chien, C. H. Lin, M. Y. Chiang, H. S. Chang, C. H. Liao, I. S. Chen, C. F. Peng and I. L. Tsai, Phytochemistry, 2012, 80, 50-57.
33 S. Yamada, F. Ono, T. Katagiri and J. Tanaka, Bull. Chem. Soc. Jpn., 1977, 50, 750.

34 W. J. Lan, W. Liu, W. L. Liang, Z. Xu, X. Le, J. Xu, C. K. Lam, D. P. Yang, H. J. Li and L. Y. Wang, Mar. Drugs, 2014, 12, 4188-4199.

35 J. Kjer, A. Debbab, A. H. Aly and P. Proksch, Nat. Protoc., 2010, 5, 479-490.

36 M. Ashour, R. Edrada, R. Ebel, V. Wray, W. Wätjen, K. Padmakumar, W. E. G. Müller, W. H. Lin and P. Proksch, J. Nat. Prod., 2006, 69, 1547-1553.

37 CLSI, Methods for Dilution Antimicrobial Susceptibility Tests for Bacteria That Grow Aerobically; Approved Standard-Ninth Edition, Clinical and Laboratory Standards Institute, 2012.

38 MacroModel; Schrödinger, LLC, 2012, http:// www.schrodinger.com/MacroModel.

39 M. J. Frisch, G. W. Trucks, H. B. Schlegel, G. E. Scuseria, M. A. Robb, J. R. Cheeseman, G. Scalmani, V. Barone, B. Mennucci, G. A. Petersson, H. Nakatsuji, M. Caricato, X. Li, H. P. Hratchian, A. F. Izmaylov, J. Bloino, G. Zheng, J. L. Sonnenberg, M. Hada, M. Ehara, K. Toyota, R. Fukuda, J. Hasegawa, M. Ishida, T. Nakajima, Y. Honda, O. Kitao, H. Nakai, T. Vreven, J. A. Montgomery Jr, J. E. Peralta, F. Ogliaro, M. Bearpark, J. J. Heyd, E. Brothers, K. N. Kudin, V. N. Staroverov, R. Kobayashi, J. Normand, K. Raghavachari, A. Rendell, J. C. Burant, S. S. Iyengar, J. Tomasi, M. Cossi, N. Rega, J. M. Millam, M. Klene, J. E. Knox, J. B. Cross, V. Bakken, C. Adamo, J. Jaramillo, R. Gomperts, R. E. Stratmann, O. Yazyev, A. J. Austin, R. Cammi, C. Pomelli, J. W. Ochterski, R. L. Martin, K. Morokuma, V. G. Zakrzewski, G. A. Voth, P. Salvador, J. J. Dannenberg, S. Dapprich, A. D. Daniels, Ö. Farkas, J. B. Foresman, J. V. Ortiz, J. Cioslowski and D. J. Fox, Gaussian 09, Revision B.01, Gaussian, Inc., Wallingford, CT, 2010.

40 P. J. Stephens and N. Harada, Chirality, 2010, 22, 229-233.

41 CHESHIRE CCAT, the Chemical Shift Repository for computed NMR scaling factors, http://cheshirenmr.info/ index.htm.

42 M. W. Lodewyk, M. R. Siebert and D. J. Tantillo, Chem. Rev., 2012, 112, 1839-1862.

43 U. Varetto, MOLEKEL, v. 5.4, Swiss National Supercomputing Centre, Manno, Switzerland, 2009. 